\title{
E-Learning in Kazakhstan: Stages of Formation and Prospects for Development
}

\author{
http://dx.doi.org/10.3991/ijac.v5i4.2210
}

\author{
Daniyar Sapargaliyev \\ Eurasian National University, Astana, Kazakhstan
}

\begin{abstract}
Today Kazakhstan is a country with a very high level of literacy. The living standards and economy in the country are growing very rapidly. But the emergence of eLearning was held stable and haphazard. This is due to many factors - later involvement in the process of society's "informatization", lack of attention to the development of distance and corporate learning. Meanwhile, e-Learning is important and a priority in education and business sectors. The Government is taking all efforts to diversify the process of implementing e-Learning for all citizens. The population of Kazakhstan is in a huge need for digital literacy. Year by year an increasing number of citizens are wishing to develop their "digital” culture. Many Kazakhs are ready to acquire new knowledge through e-Learning at universities and in the workplaces. In this paper we will consider the formation of e-Learning in Kazakhstan and contemporary challenges for the further development of eLearning.
\end{abstract}

Index Terms-e-Learning, ICT, government program, informatization.

\section{INTRODUCTION}

The introduction of e-Learning in Kazakhstan began in 1997. At this time, the government was taking the first steps in development of electronic forms of learning and development of ICT in education. In the next 15 years, Kazakhstan has continuously developed e-Learning and builds capacity for increased use of new technologies in education. This growth has coincided with the rapid spread of the Internet in Kazakhstan.

According to Internet World Stats, Kazakhstan had $5,300,000$ Internet users or $34.3 \%$ of the population in 2010 (0.5\% in 2000 respectively) [1]. Latchem and Jung argue that the break up of the Soviet Union, the Central Asian countries of Kyrgyzstan, Tajikistan, Uzbekistan, Kazakhstan and Turkmenistan have been in great need of social, economic and educational reform.

The Asian Development Bank (ABD) reports that Kazakhstan, Kyrgyzstan, Uzbekistan, Mongolia and Tajikistan are increasingly aware of the role that ICT can play in modernizing their education systems. The ADB has helped Kazakhstan and Uzbekistan with their ICT in Basic Education Projects, Kazakhstan with its Educational Rehabilitation and Management Improvement Project. The World Bank, UNESCO, UNDP and other agencies have assisted in the development of their distance learning systems and Internet access. Several universities offer distance education in Kazakhstan where the economy is booming [2].
One of the first e-Learning initiatives was the workshop that was taking place in 2003. There was a two week faceto-face course and an eight week online training course is being organized with UNESCO's support by the AsiaPacific Institute for Broadcasting and the School of Mass Media Training at Kazakh National University. Members of journalism faculties of universities and practicing journalists in the Central Asia Region are participating in the course [3].

Kazakh scientists Nurgalieva, Tazhigulova and Artykbayeva describe the development of e-Learning in different levels of education. For the last 15 years there were created 41 e-textbooks in the areas of transport, construction technology, equipment, food processing, services, specialty arts and culture, general engineering, aeronautical engineering, electricity and thermal power generation. The overall need for educational publications is about 2780 units both in Kazakh and Russian languages, particularly on subjects of a professional and specialized nature. Besides books, Kazakhstan colleges would also be procuring electronic teaching systems, ecase studies systems, administrative systems and elibraries. Totally, colleges demand in 7455 units of e-book in Kazakh and Russian languages. In schools, $100 \%$ of content have been converted into digital interactive programs, for all levels [4].

In 2011, Former UK Education Secretary, Rt. Hon. Charles Clarke recognizes the excellence of a Kazakhstan e-Learning initiative that involves over 20,000 classrooms and 40,000 teachers. Since 2007, this bold initiative, led by the Ministry of Education and Science and supported by the e-Learning Partnership for Kazakhstan, has seen over 20,000 interactive classrooms for science and language teaching installed in schools across the country. Over 40,000 teachers have been trained on the use of new interactive classroom pedagogies and innovative interactive classroom technologies such as interactive whiteboards, student voting systems and scientific data logging kits. A key element in the success of this program has been the use of "virtual classrooms" to deliver on-line lessons and teacher training via Internet [5].

In spite of obvious successes in the field of e-Learning, Kazakhstan system of education has a shortage of skilled labor that could contribute to the necessary level of eLearning in different areas. In this article we will try to consider the milestones in the development of e-Learning, problems of education system's informatization and the government's plans for improving situations in e-Learning. 


\section{BACKGROUND}

Kazakhstan's educational community over the past ten years has developed approaches in the study and implementation of e-Learning in national education system. Many researchers have focused on studying the problems and peculiarities of the use of ICT in higher education. For example, Mukushev develops the concept of legal education's informatization in high schools. The author has created a model of e-Learning for students in terms of information system. The author has developed the electronic textbook "Fundamentals of law" and made assessment and control program for computer-based testing [6].

Kadyrbayeva identifies the opportunities for selfteaching of students in e-Learning environment. The author justifies levels, criteria and indicators of readiness for college students' cognitive activity in e-Learning [7].

Usenov proves the feasibility of using information resources to improve training of students. The author has identified the most effective methods for using of electronic resources. The author defined set of requirements (psychological, pedagogical, ergonomic, and functional) in teaching. The author has created the learning model that focuses on the formation of students' ability to select and use electronic resources in practice [8].

Nurgaliyeva describes the Kazakhstani electronic textbooks that developed the technology of modular learning. E-textbooks represent an automated process of learning from the target to result in a coherent system of interrelated components: the module - hypertext - online work- control of educational achievement [9].

Kurmanova creates the conceptual model of the Kazakh language learning by using ICT in higher education. The author suggested that the development of e-Learning for Kazakh language study is still need the pedagogical improvements [10].

Also, researchers are considering the use of e-Learning in the study of various disciplines. For example, Abuova determines the structure of e-Learning for biology and chemistry. The author has proved the effectiveness of teaching biology and chemistry in the integrative-based information platform that promotes motivation and methodological support for students and teachers [11]. Bostanov argues the need of using educational electronic media for teaching. The author defined the principles of educational electronic media, based on the allocation of hierarchical structures in the content of e-Learning content [12].

It should be noted the international collaboration of universities for introduction of distance and e-Learning. One of the first initiatives in this area was described by Latchem et al. In 2001 the Board of Trustees established the Internet-based Distance Education Department or TÜRTEP (Distance Education Program Using Turkish Language). It was envisaged that using Internet technologies would help to achieve the university's ideals of connecting Turkish-speaking countries by capitalizing on the knowledge and skills of Turkish and Kazakh academics, attract mature-aged learners already in jobs and enable the university to collaborate with other universities, nationally and internationally [13].
Imadildayeva and Zhaidarbek argue that Kazakh National University as of the largest public university in Kazakhstan is meeting challenges to introduce technology enhanced learning. The university's current system is not reliable; also it is outdated in terms of its structure and need to be replaced with e-Learning system. The analysis of the data shows positive attitude among the students and teachers for implementing an e-Learning system. The system of e-Learning is based on Moodle software that offers courses for students in Kazakh National University [14].

Nurgaliyeva and Artykbayeva point out that development of e-Learning in Kazakhstan has special social significance and relevance. For example, many people live in villages and towns that are far from the administrative and regional centers; schools of small towns lack teaching staff and have poor methodological provision of information and learning resources; more than 2 million people need annual retraining [15].

Zhakupova, Gazdiyeva and Tavluy note that electronic learning is actively introduced into the national high education. Kazakhstani high education moves towards the annexation of the national education system to the Bologna education model, involvement into the European and world educational system with the preservation of the good experience of the previous national educational system [16].

However, Kazakhstani scientists are still investigating the development and implementation of e-Learning in education. Many projects and initiatives mostly carried out in secondary and higher education and almost did not affect of e-Learning in the workplaces and business sector. This area requires further in-depth study in the future.

\section{CORPORATE E-LEARNING}

The development of e-Learning in the workplace has a recent history of Kazakhstan. This is due primarily to the fact that many companies are not aware of advantages and effectiveness in implementation of corporate e-Learning. The main directions in Kazakhstani corporate e-Learning are financial and IT sectors.

Kasenova (2011) argues that in Kazakhstan, e-Learning is embedded mainly in industrial companies or banks. Over the past three years, these companies increased demand for e-learning courses designed for specific tasks. There are e-courses on various topics: Project Management, Leadership, Finance and different courses for IT sector [17].

One of the first examples of corporate financial education is "Center for learning, retraining and advanced training of Kazakhstani financial system" that was established in 2007. The purpose of the Center is provision of qualified personnel in various sectors of economy. The Center had created electronic system for the management and dissemination of knowledge, best practices in the financial system of Kazakhstan [18].

The first center of Internet Education (www.mnogo.kz) was founded in 2011. In early 2012, this web resource launched a special project: "Internet Avenue". This project is designed for executives, developers of websites, managers and marketers. The first seminars and lectures: "Conquer the Internet space" was focused on the major theoretical and practical issues in the promotion of social media in Kazakhstan [19]. 
In 2012, Kazakhstani construction company "BI Group" opened a corporate University. The first step was an internship program for students of Kazakh universities, and development of corporate system of education. Corporate University aims to provide long-term needs of the company for qualified employees [20].

Thus, in recent years Kazakhstan had sharp rise in the projects and initiatives in e-Learning in the workplace. The need for e-courses and corporate distance training is growing up. However, Kazakhstan has a noticeable shortage in professionals, who can support corporate eLearning projects.

\section{Milestones in the DeVelopment of E- LEARNING}

The development of e-Learning in Kazakhstan was held in accordance with governmental programs and concepts. We have identified three milestones in the development of e-Learning in the period from 1997 to 2010 and covered the basic plans for the total implementation of eLearning by 2020.

\section{A. The State Program of Informatization of Secondary Education System for 1997-2002}

In September 1997 the government approved the State Program of Informatization of secondary education system for 1997-2002 [21]. The purpose of this Program was the creation of unit information and educational system in Kazakhstan. Program was divided in 5 phases: for the first phase (1997/98 academic year) there were equipped the secondary schools in cities and regional centers. In the second phase (1998/99 school year) there were started the computerization of secondary schools. In the third phase (1999/2000 academic year) it was ended the period of computerization of all secondary schools. In the fourth phase (2000/01 academic year) was carried out the computerization of all primary schools. Finally, in the fifth phase (2001/02 academic year) there was completed the education management information system. As the results of Program implementation there were created flexible, methodological and technical support of education system, the development of information culture and the basics of computer literacy in schools.

\section{B. The Concept of Informatization of Education System in Kazakhstan for 2002-2004}

In August 2001, government adopted the Concept of Informatization of Education System in Kazakhstan for 2002-2004 [22]. The main goal of informatization of the education system is the creation of a unified educational information environment in the Republic of Kazakhstan and the integration of information system into the world educational space. The Concept is scheduled for implementation from 2002 to 2005 and covered all levels of primary and secondary education. However, there were no systematic coordination and purposeful planning and financing of Concept. In the field of distance education, some universities started to research and development this sphere. E-Learning carried out mainly by enthusiasts who have developed a series of electronic textbooks for university courses.

\section{The State Program for the Development of Education in Kazakhstan for 2005-2010}

In October 2004 the government presented the State Program for the Development of Education in Kazakhstan for 2005-2010 [23]. The aim of Program was the modernization of education system and improvement of human resource quality. One of the main directions of Program was the total computerization. The expected outcomes of the Program were implemented in 2 phases. In the first phase (2005-2007) there were increased use of ICT in educational process and improved the quality of education by providing data access facilities to electronic resources. In the second phase (2008-2010) there were developed and implemented the modern e-textbooks for all subjects of secondary school. In 2010 the number of personal computers in schools has reached to the ratio of 1 computer per 20 students.

\section{The State Program for Development of Education in Kazakhstan for 2011-2020}

In December 2010, the government approved the State Program for Development of Education in Kazakhstan for 2011-2020 [24]. The main objective of the program is to increase the competitiveness of education, human capital development by providing access to quality education for sustainable economic growth. One of the main directions of education program is the e-Learning development in Kazakhstan. The purpose of this direction is to ensure equal access for all participants in the educational process to the best educational resources and technologies. The introduction of e-Learning will require changes and additions to the series of regulatory documents. By 2012, it will be made the State Educational Standards of higher, technical and vocational education in terms of training teachers to work with national e-Learning system. There will be developed and approved requirements for the creation of electronic textbooks and teaching materials in e-Learning system. It is expected that 2012 will start the training of teachers on the use of e-Learning in practice. More than $90 \%$ of educational institutions, especially schools, working on a pilot program of resource centers will be connected to Internet. It is planned to provide a complete digital educational content for secondary, technical and vocational education in the public domain. According to Program all high schools will be provided $100 \%$ access to broadband Internet by 2020 .

Obviously, that in the last 15 years, the government made repeated attempts to develop e-Learning at all levels of education. Many tasks in the programs and concepts were only partially implemented and were not successful. Nevertheless, progress in the development of e-Learning is evident, although in first of all it was shown by active use of ICT in education.

\section{CONCLUSION}

E-Learning is becoming the main form of learning for the next ten years in Kazakhstan. Educational community actively explores and implements various ways and methods of use ICT in education. The main criterion for the quality of teaching in Kazakhstan is the ability to effectively use information resources and expand knowledge. The education system and corporate learning are undergoing a global restructuring and rebirth, in relation to the total implementation of e-Learning. This 


\section{SHORT PAPER \\ E-LEARNING IN KAZAKHSTAN: STAGES OF FORMATION AND PROSPECTS FOR DEVELOPMENT}

process requires a detailed study in order to avoid mistakes in planning for further reforms. As it was shown by previous experience the systematic execution and financial support had helped the government to issue general features of informatization. We hope that the new government initiatives will fundamentally change the situation until 2020 and successfully implement eLearning as a major landmark in Kazakhstan.

\section{REFERENCES}

[1] Internet World Stats. Internet usage, broadband and telecommunications reports, Kazakhstan http://www.internetworldstats.com/asia/kz.html.

[2] C.Latchem and I.Jung, Distance and Blended Learning in Asia, Open and Flexible Learning Series, 2009, pp. 280.

[3] UNESCO, e-Learning for Journalists Training in Central Asia, 2003, http://portal.unesco.org/ci/en/ev.php-URL ID $=12060 \& U R L$ DO=DO_TOPIC\&URL_SECTION $=201 . \mathrm{html}$.

[4] G.Nurgalieva, A. Tazhigulova and Y. Artykbayeva 'eLearning in Kazakhstan', in Demiray, U. et al (Eds.), E-Learning Practices Volume I, Cases on challenges facing e-learning and national development: Institutional Studies and Practices, Anadolu University, 2010, pp. 335-354.

[5] C.Clarke, Congratulates Kazakhstan on their eLearning Initiative, 2011, http://www.prlog.org/11709768-charles-clarke-congratulat es-kazakhstan-on-their-elearning-initiative.pdf

[6] S.B.Mukushev, "Правовая подготовка будущих специалистов в условиях информатизации образования (на примере неюридических специальностей ВУЗа)," PhD dissertation, 2010, pp. 152, unpublished.

[7] G.T.Kadyrbayeva, "Методика использования электронного обучающего комплекса в самостоятельной деятельности учащихся колледжей (на примере обучения информатике)," $P h D$ dissertation, 2010, pp.140, unpublished.

[8] S.S.Usenov, "Теоретико-методические основы применения и оценки качества электронных ресурсов для обучения информатике в вузе," Ed.D dissertation, 2009, pр. 360, unpublished.

[9] G.K.Nurgaliyeva, Концепиия электронного обучения как информационно-образовательной среды, E-Journal of pedagogical articles on informatization of education (Электронный журнал научно-педагогических статей по информатизации образования), http://moodle.nci.kz/file.php/ 1/ZHURNAL/Nurgalieva_rus.doc

[10] B.Zh.Kurmanova, "Научно-методические основы преподавания казахского языка в высших учебных заведениях с использованием системы информационных технологий," Ed.D dissertation, 2010, pp. 384, unpublished.

[11] B.D.Abuova, "Методические особенности обучения биологии и химии в педагогических учебных заведениях на интегративно-информационной основе," $P h D$ dissertation, 2009, pp.168, unpublished.

[12] B.G.Bostanov, "Методические основы обучения будущих учителей информатики созданию и использованию электронных образовательных средств," PhD dissertation, 2009, pp 118, unpublished.
[13] C. Latchem, N. Simsek, O.C. Balta, O. Torkul, I. H. Cedimoglu and A. Altunkopru, Are We There Yet? A Progress Report from Three Turkish University Pioneers in Distance Education and ELearning, International Review of Research in Open and Distance Learning, Volume 10, Number 2, 2009, pp. 2-15.

[14] K.Imadildayeva and A.Zhaidarbek, "Developing e-learning for Kazakh National University" Masrter's thesis, 2010, pp. 238 , http://eprints.utm.my/11057/

[15] G.Nurgaliyeva and E.Artykbayeva, "Content Provision for Information and Educational Environment in the Republic of Kazakhstan", ICT in Teacher Education: Policy, Open Educational Resources and Partnership, 2010, pp. 112-117 http://iite.unesco.org/pics/publications/en/files/3214684.pdf\#page $=113$

[16] A. Zhakupova, B. Gazdiyeva and M. Tavluy, "Innovative component of modern higher education in the Republic of Kazakhstan," EDULEARN11 Proceedings, pp. 3223-3229, 3rd International Conference on Education and New Learning Technologies, July, 2011.

[17] A. Kasenova, "Спрос на e-Learning в Казахстане растет." http://profinance.kz/news/articles/24519-spros-na-e-learning-vkazastane-rastet.html

[18] ECMF. (2007). History of ECMF. http://www.ecmf.kz/ru/company/history.php

[19] Profit.kz (2012). В Казахстане открылся центр интернетобразования. http://www.profit.kz/news/8716-V-Kazahstaneotkrilsya-centr-internet-obrazovaniya/\#.UGdxlovG9ck

[20] Smart-Edu.Com (2012). В Казахстане открывается корпоративный университет BI Group. http://www.smartedu.com/bi-group-orporate-university.html

[21] Ministry of Education and Science of Kazakhstan, "Государственная программа информатизации системы среднего образования", 1997, http://www.unesco.kz/rcie/ data/progr_inf1997.htm.

[22] Ministry of Education and Science of Kazakhstan, "Концепция информатизации системы образования Республики Казахстан на 2002-2004 годы,” 2001， http://www.unesco.kz/rcie/ data/koncepcija_inf2002.htm.

[23] Ministry of Education and Science of Kazakhstan, "Государственная программа развития образования в Республике Казахстан на 2005-2010 годы,” 2004, http://kazpravda.kz/_pdf/161004program.pdf.

[24] Ministry of Education and Science of Kazakhstan, "Государственная программа развития образования Республики Казахстан на 2011-2020 годы,” 2010, http://www.edu.gov.kz/ru/zakonodatelstvo/gosudarstvennaja prog ramma_razvitija_obrazovanija/gosudarstvennaja_programma_razv itija_obrazovanija_respubliki_kazakhstan_na_2011_2020_gody/.

\section{AUTHOR}

D. Sapargaliyev is with Department of Social Sciences, Eurasian National University, 5, Munaitpasov Street, 010008, Astana, Kazakhstan (e-mail: dsapargalieff@gmail.com).

Received 21 July 2012. Published as resubmitted by the author 14 November 2012. 